\author{
Michal Adamczyk \\ AGH Akademia Górniczo-Hutnicza \\ e-mail: michal.adamczyk@agh.edu.pl
}

\title{
ELEMENTY POLITYKI PROINNOWACYJNEJ W OPINII PRZEDSTAWICIELI KRAKOWSKICH ORGANIZACJI TYPU STARTUP*
}

\section{ELEMENTS OF PRO-INNOVATION POLICY \\ IN THE OPINION OF REPRESENTATIVES \\ OF START-UP COMPANIES FROM CRACOW}

\author{
DOI: 10.15611/pn.2018.527.02 \\ JEL Classification: H25, M13, O38
}

\begin{abstract}
Streszczenie: Jednym z kluczowych czynników warunkujących rozwój współczesnej gospodarki jest jej zdolność do generowania i absorpcji innowacji. Stąd działania nakierowane na rozwój innowacyjności stanowią bardzo ważny element polityki gospodarczej realizowanej przez władze publiczne różnych szczebli. Aktorem odgrywającym coraz większą rolę w ekosystemie innowacji są podmioty typu startup, które stają się także coraz częściej adresatami polityk publicznych. Celem artykułu jest przedstawienie czynników i barier rozwoju oraz potrzeb krakowskich organizacji typu startup, a także prezentacja wybranych instrumentów polityki proinnowacyjnej, prowadzonej głównie na szczeblu lokalnym. Badania prowadzono z wykorzystaniem studiów literaturowych, analizy dokumentów oraz danych jakościowych zebranych w drodze wywiadów.
\end{abstract}

Słowa kluczowe: startup, polityka ekonomiczna, ekosystem innowacji.

Summary: Ability to generate and absorb innovations is one of the key factors determining development of modern economy. Therefore, actions aimed at developing innovation are a very important element of economic policy implemented by public authorities at various levels. Start-up companies play an increasingly important role in the innovation ecosystem and as recipients of public policies. This paper presents factors and barriers to the development and needs of start-up organizations in Cracow. Selected pro-innovation policy instruments will be presented mainly at the local level. Presented research was based on literature review, document analysis and qualitative data collected through interviews.

Keywords: start-up, public policy, ecosystem of innovation.

* Badania finansowane w ramach grantu dziekańskiego AGH, nr umowy 15/11.200.330. 


\section{Wstęp}

W coraz większym stopniu rozwój gospodarczy jest związany z poziomem innowacyjności tworzących ją przedsiębiorstw [Puślecki 2017]. Z kolei istotą innowacyjnej gospodarki jest ciągłe dążenie przedsiębiorców do testowania i wprowadzania do rzeczywistości gospodarczej wyników badań naukowych, prac rozwojowych, nowych koncepcji, pomysłów i wynalazków [Węgrzyn 2014].

Stąd dużej wagi we współczesnym systemie innowacji nabierają niewielkie i zwinne (agile) organizacje typu startup, które w naturalny sposób potrafią zamieniać innowacje na wartość dla klienta poprzez prowadzenie eksperymentów rynkowych [Orłowski 2013; Płoszajski 2011].

Wsparcie organizacji typu startup staje się także elementem polityk publicznych na różnych szczeblach. Od 2015 roku Narodowe Centrum Badań i Rozwoju realizuje program Bridge Alfa, którego celem jest wsparcie funduszy inwestujących w startupy na wczesnym etapie rozwoju. W 2017 roku Polska Agencja Rozwoju Przedsiębiorczości uruchomiła pilotażowy projekt ScaleUP, który ma wspierać współpracę startupów z dużymi partnerami branżowymi. Także władze samorządowe deklarują wsparcie tej formy przedsiębiorczości. W Krakowie od 2015 roku organizowany jest Tydzień Startupów, a od 2013 roku Małopolski Urząd Marszałkowski wspiera wydarzenia startupowe.

Celem artykułu jest przedstawienie wyzwań i problemów, z jakimi spotykają się przedsiębiorcy prowadzący startup w kontekście polityki gospodarczej, ze szczególnym uwzględnieniem szczebla lokalnego. Prezentowane w artykule badania prowadzone były w Krakowie. Zasadnicza ich część dotyczyła lat 2014-2015, a więc okresu, kiedy planowane lub wdrażane były funkcjonujące obecnie mechanizmy wspierania startupów. Prowadzone w latach 2015-2018 obserwacje uczestniczące pozwoliły na dodatkową analizę podjętych działań.

W pierwszej części artykułu umieszczono przegląd literatury dotyczącej polityki proinnowacyjnej oraz przedstawiono specyfikę organizacji typu startup. W drugiej części znajduje się opis metody badawczej i wyniki badań własnych. Na końcu umieszczono wnioski, podsumowanie oraz propozycje dalszych badań.

\section{Wybrane elementy systemu innowacji}

\subsection{Instrumenty polityk proinnowacyjnych}

Uważa się, iż inwestycjom w rozwój technologii i innowacji towarzyszą efekty zewnętrzne (transfer wiedzy, wzrost innowacyjności), które znacznie przewyższają zwroty z inwestycji poszczególnych przedsiębiorstw. Stąd kluczowego znaczenia nabiera prowadzenie przez władze publiczne spójnej polityki proinnowacyjnej [Zegarowicz, Wildowicz-Giegiel 2017; Żabiński 2015]. 
Instrumenty, jakimi władze publiczne oddziałują na gospodarkę, można podzielić na: bezpośrednie (wydatki na działalność $\mathrm{B}+\mathrm{R}$ w sektorze publicznym, dotacje dla podmiotów prywatnych, tworzenie organizacji wspierających proces tworzenia innowacji, finansowanie działalności edukacyjnej i szkoleniowej) oraz pośrednie (kreowanie określonego otoczenia prawnego, podatkowego i instytucjonalnego).

Angażowanie środków publicznych do bezpośredniego wsparcia wybranych inicjatyw biznesowych budzi spore wątpliwości, ponieważ z jednej strony zniechęca przedsiębiorców do zachowań rynkowych, a z drugiej zmusza instytucje publiczne do podejmowania decyzji biznesowych, do czego z natury nie są one przygotowane [Jegorow 2017].

Analiza polityk proinnowacyjnych w krajach OECD wykazała, iż stosowanie wyłącznie bezpośrednich instrumentów, takich jak granty na badania, przynosi negatywne skutki z co najmniej dwóch powodów [Zegarowicz, Wildowicz-Giegiel 2017]:

- Podmioty prywatne wykorzystują subsydia rządowe alternatywnie do inwestowania własnego kapitału, co ogólnie zmniejsza wielkość inwestycji w B+R $\mathrm{w}$ danej gospodarce.

- Inwestycja dużych środków publicznych w B+R generuje sztuczny popyt, co z kolei prowadzi do zwiększenia kosztów tego typu działalności i w konsekwencji zmniejsza zainteresowanie sektora prywatnego.

Do bezpośrednich instrumentów wsparcia działalności innowacyjnej można także zaliczyć dotacje dla uczelni wyższych. Zdaniem części teoretyków, a także niektórych przedstawicieli biznesu, to właśnie tzw. miękkie finansowanie uczelni wyższych w Polsce jest ważnym czynnikiem zniechęcającym środowisko akademickie do współpracy z biznesem [Orłowski 2013; Urmański (red.) 2016].

Lepsze efekty zdają się przynosić ulgi podatkowe, które powodują obniżenie kosztów przedsiębiorców inwestujących w $\mathrm{B}+\mathrm{R}$, przy jednoczesnym pozostawieniu im swobody w kształtowaniu własnej polityki rozwojowej [Żabiński 2015]. Istotnym elementem tego mechanizmu jest założenie, iż władze publiczne powinny wspierać istniejące przedsięwzięcia, a nie kreować nowe działania biznesowe.

Ważnym elementem polityki proinnowacyjnej jest także wspieranie instytucji pośredniczących $\mathrm{w}$ transferze wiedzy, koordynujących sieci międzyorganizacyjne czy inicjujących powstawanie klastrów [Puślecki 2017]. Prowadzona przez Komisję Europejską polityka w tym zakresie najczęściej wpisuje się w jeden z dwóch zasadniczych modeli: wspieranie koordynatorów klastrów i relacji pomiędzy podmiotami w ramach danej sieci lub dotowanie konkretnych przedsięwzięć realizowanych w ramach klastra lub określonej sieci międzyorganizacyjnej (np. wspólne projekty B+R czy rozbudowa wspólnej infrastruktury) [Piątyszek-Pych 2017].

\subsection{Organizacje typu startup}

Wysoko rozwinięta gospodarka opiera się na innowacjach, które tworzą wartości dla klienta. Dobrze skonstruowany system innowacji koncentruje się na stronie po- 
pytowej, a więc tworzeniu nowatorskich rozwiązań w odpowiedzi na realnie zidentyfikowane potrzeby konsumentów [Puślecki 2017; Węgrzyn 2014]. Organizacje typu startup doskonale wpisują się w ten model.

Samo pojęcie „startup” nie znajduje jednoznacznej definicji w polskiej literaturze naukowej. Najczęściej jest ono rozumiane jako nowo powstały podmiot gospodarczy, bez względu na rodzaj działalności czy filozofię działania [Gemzik-Salwach 2014; Korpysa 2012; Kulczycki 2014; Smus 2014]. Z kolei Bursiak [2013] za podstawowe kryterium definicji startupu uważa sposób jego finansowania poprzez objęcie udziałów przez fundusze inwestycyjne.

W literaturze branżowej najczęściej przywoływane są dwie definicje autorstwa Erica Riesa oraz Steve’a Blanka. Według nich startup to odpowiednio: „organizacja, która tworzy produkty i usługi w warunkach skrajnej niepewności” [Ries 2011] lub „tymczasowa organizacja, która poszukuje rentownego, skalowalnego i powtarzalnego modelu biznesowego" [Blank, Dorf 2013]. Obaj autorzy rozumieją zatem startup jako pewnego rodzaju model działania organizacji opartej na innowacjach.

Z kolei Skala [2017] proponuje „,spiralną definicję”, według której startup cechują ograniczone zasoby oraz ograniczony (lub nieistniejący) popyt na jej produkty. Ogólnie można zatem przyjąć, iż kluczowymi cechami organizacji typu startup są [Adamczyk 2016]:

1. Dążenie do stworzenia nowej wartości dla klienta poprzez wprowadzenie na rynek innowacyjnej usługi lub produktu.

2. Wykorzystywanie zewnętrznego finansowania od inwestora lub aktywne poszukiwanie takiej formy wsparcia.

3. Prowadzenie eksperymentów rynkowych, tj. wprowadzanie kolejnych wersji innowacyjnego produktu celem zbierania pogłębionych opinii na jego temat.

Przywołany powyżej przegląd literatury wskazuje, iż pojęcie „startup” nie posiada tak ostrej definicji jak np. „małe lub średnie przedsiębiorstwo”, co nastręcza trudności podczas projektowania efektywnych polityk publicznych czy realizacji badań w tym zakresie.

\section{Czynniki i bariery rozwoju organizacji typu startup na przykładzie Krakowa}

\subsection{Metoda i charakterystyka próby badawczej}

Tradycyjne wskaźniki pomiaru innowacyjności, jak liczba patentów, poziom zatrudnienia w branżach wiedzochłonnych czy udział towarów hi-tech w bilansie handlowym, są niewystarczające do wyczerpującego opisu zjawisk innowacyjnej gospodarki [Węgrzyn 2014; Pachura 2017]. Analizę ilościową utrudnia także brak rzetelnych danych statystycznych dotyczących realizowanych polityk publicznych [Jegorow 2017]. W celu zidentyfikowania czynników determinujących rozwój startupów zastosowano zatem metody badań jakościowych w perspektywie eksploracyjnej, 
polegającej na analizie zbieranego materiału empirycznego z ograniczoną liczbą założeń wstępnych.

W kontekście omawianych zjawisk i badanych podmiotów kluczowymi aspektami są odległość fizyczna oraz historycznie ukształtowana kultura organizacyjna danego systemu innowacji [Puślecki 2017; Żabiński 2015]. Stąd zakres zbieranego materiału empirycznego został ograniczony terytorialnie do krakowskiego ekosystemu startupowego. W artykule wykorzystano analizę dokumentów (w tym protokołów z posiedzeń i raportów ze spotkań nieformalnych) oraz wywiadów prowadzonych z przedstawicielami krakowskich startupów.

\subsection{Wnioski z konferencji „Kraków Miastem Startupów?”}

Jednym z pierwszych oficjalnych dokumentów dotyczących startupów w Krakowie jest uchwała Rady Miasta z 5 listopada 2014 w sprawie „wspierania rodzimych inicjatyw kreatywnych i startupów". Wart bliższej analizy jest nietypowy i po części nieoficjalny proces konsultacyjny, który poprzedził jej przyjęcie.

Pierwszym impulsem do przyjęcia wspomnianej uchwały było posiedzenie Komisji Rozwoju i Innowacji RMK (29.05.2014), w którym udział wzięli przedstawiciele krakowskich startupów. Zebrani stwierdzili, iż ważnym celem jest „wykreowanie jednolitego systemu, dzięki któremu małe firmy, wielcy inwestorzy, jak i organizacje wspomagające będą mogli porozumiewać się w jednym miejscu i na jednej płaszczyźnie”, a Urząd Miasta, ,jako miejsce przyjazne tego typu inicjatywom", powinien ten cel wspierać.

Po spotkaniu zawiązała się nieformalna grupa, która odbyła dwa robocze spotkania - ich celem było przeprowadzenie konsultacji w środowisku startupowym i zbudowanie legitymizacji dla prowadzonych działań. Efektem pracy grupy była konferencja w formule Open Space Technology (OST), która odbyła się 5 lipca 2014 roku. Zgodnie z założeniami OST konferencja miała charakter otwarty, bez narzuconej agendy. Każdy uczestnik mógł zaproponować temat i jeśli zebrała się odpowiednia liczba chętnych, otwierano dyskusję na dany temat w jednej z czterech podgrup. Spotkanie zatytułowano: „Kraków Miastem Startupów?”. Pytajnik w nazwie miał skłaniać do refleksji, czy Kraków jest miejscem przyjaznym dla startupów.

Udostępniony przez organizatorów raport zawierający zapis dyskusji we wszystkich podgrupach został potraktowany jako materiał empiryczny i poddany analizie. Podczas konferencji poruszono łącznie 12 tematów. Dwa z nich dotyczyły bardzo konkretnych projektów: stworzenia parku kultury oraz studiów podyplomowych na jednej z krakowskich uczelni. Pozostałe dyskusje miały charakter bardziej ogólny i podzielić je można na dwie grupy: praktyczne aspekty związane z zarządzaniem organizacją typu startup oraz kwestie dotyczące wspierania startupów przez władze publiczne.

W ramach pierwszej grupy tematów uczestnicy dyskutowali o budowaniu zespołów startupowych (poznawanie ludzi, tworzenie relacji), prawnych aspektach prowadzenia startupu (prawo spółek handlowych, ochrona własności intelektual- 
nej), stawianiu pierwszych kroków w biznesie (pozyskanie pierwszego klienta, narzędzia i koncepcje zarządzania startupem), pozyskiwaniu finansowania zewnętrznego.

W drugim obszarze tematycznym poruszone zostały zagadnienia wpisujące się w tematykę polityk publicznych. Pierwszy zespół rozmawiał na temat konieczności stworzenia ,inforgrafiki”, czyli graficznej mapy ekosystemu startupowego w Krakowie, na której mogły się znaleźć informacje o instytucjach i oferowanych możliwościach wsparcia na poszczególnych etapach rozwoju startupu. Uczestnicy podkreślali, że mapa powinna bazować na informacjach już rozproszonych w różnych miejscach. Drugi zespół poruszył problem udostępniania danych publicznych (tzw. Open Data) w Internecie. Trzecia grupa skupiła się na bardzo ogólnej tematyce wspierania startupów przez miasto. Pojawiła się tutaj koncepcja „parasola”, jakim powinny być władze miasta w stosunku do inicjatyw organizowanych przez społeczność startupową. Dyskutanci zwrócili także uwagę na potrzebę wspólnej przestrzeni - zarówno fizycznej (neutralne miejsca spotkań), jak i wirtualnej (wydzielona część miejskiej strony internetowej poświęcona wyłącznie startupom). Pojawił się także postulat powołania po stronie Urzędu Miasta koordynatora ds. współpracy ze startupami oraz wykorzystania pozycji urzędu do promocji innowacyjnych przedsiębiorstw na arenie krajowej i międzynarodowej.

Czwarty zespół dyskutował na temat promocji Krakowa jako „miasta startupów". O ile dyskutanci byli zgodni, iż Kraków powinien być tak postrzegany, to zdania były podzielone, czy kreowaniem takiego wizerunku powinien zajmować się urząd, czy też sama społeczność startupowa. Ostatnia grupa skupiła się na wypracowaniu konkretnych celów i działań, jakie zostaną podjęte po konferencji w ramach nieformalnej grupy „Kraków Miastem Startupów”. Dyskutanci przede wszystkim uznali, że konieczna jest lepsza organizacja społeczności startupowej, a także poznanie potrzeb miasta i próba powiązania obu stron. Podkreślono wagę edukacji i usystematyzowanej wymiany wiedzy.

\subsection{Finansowe, prawne i organizacyjne bariery rozwoju startupów}

W połowie 2015 roku, a więc pół roku po przyjęciu uchwały o wspieraniu startupów przez Radę Miasta i w trakcie tworzenia przez Urząd Miasta konkretnych instrumentów wsparcia, przeprowadzono badanie pilotażowe w postaci 10 wywiadów pogłębionych z osobami prowadzącymi startupy w Krakowie. Transkrypcje wywiadów poddane zostały analizie techniką nadawania kodów znaczeniowych [Charmaz 2009; Konecki 2012]. Dla zapewnienia anonimowości rozmówcy zostali oznaczeni literami od A do J.

Badani byli pytani o wyzwania, z jakimi aktualnie się mierzą, o ogólną ocenę działań władz samorządowych oraz o sugestie działań dla władz publicznych różnych szczebli. W toku analizy ich wypowiedzi podzielone zostały na trzy aspekty: finansowe, prawne i organizacyjne. 
Pozyskanie inwestora jest jednym z kluczowych elementów prowadzenia startupu, dlatego miarą dobrze rozwiniętego ekosystemu innowacji jest dostęp do kapitału. Zdaniem badanych w Polsce istnieją odpowiednie fundusze na wsparcie startupów. Wyzwaniem nie jest ilość kapitału, ale sposób, w jaki jest zarządzany.

W szczególności bardzo źle oceniono sposób wydatkowania środków z Unii Europejskiej, zarówno dotacje w ramach programu Innowacyjna Gospodarka, jak i granty na szkolenie w ramach programu Kapitał Ludzki. Rozmówca oznaczony jako C nie mógł np. otrzymać wsparcia z NCBiR na prowadzone badania w obszarze druku 3D, ponieważ minimalna kwota dotacji to $2 \mathrm{mln}$ złotych, a on wycenił projekt na 400 tys. i nie był w stanie pokryć $25 \%$ wkładu własnego w przypadku wyższej dotacji.

A: Dostępnych jest wiele kursów odnośnie zarządzania, ale nie do końca spełniają swoją rolę. Dofinansowane z Unii Europejskiej niewiele nauczyły, pozostawały w oderwaniu od tego, czym jest startup.

I: Jak widzę logo, że to [dana usługa] jest dotowane z Unii to już podejrzewam, że to jest kiepska usługa.

Rozmówcy C i F zauważyli, że polskie fundusze boją się ryzyka i przez to oferują bardzo niskie wyceny startupów, które nie dają możliwości szybkiego rozwoju w skali globalnej. Z kolei B zauważa, iż problemem polskich funduszy jest bazowanie wyłącznie na środkach publicznych i wynikający z tego brak doświadczenia biznesowego, którego powinni dostarczać inwestorzy prywatni.

F: Za 800000 nie zrobi się start-upu. [...] Z takim założeniem nie można konkurować na globalnych rynkach. Przy drugiej rundzie musiałem uświadamiać inwestorów, że $2 \mathrm{mln}$ to nie jest dużo.

Kolejną grupą wyzwań, z jakimi spotykają się rozmówcy, były kwestie prawne. Sześciu z dziesięciu badanych przedsiębiorców wśród istotnych problemów wymieniło podatki oraz składki na ubezpieczenie społeczne. Największym wyzwaniem dla początkujących kilkuosobowych przedsiębiorstw nie jest jednak wysokość podatków, ale nadmiernie rozbudowane formalności. Dwójka rozmówców zwróciła uwagę na inne problemy prawne niż uproszczenie procedur: I wspomniał o wprowadzeniu ulg podatkowych na innowacje, a E postulował ułatwienie procedur wizowych dla przedsiębiorców ze Wschodu.

C: W pierwszym miesiącu byliśmy 7 razy w urzędzie skarbowym, bo coś było nie tak.

F: [Jedna z 3 wspólników] zajmuje się wyłącznie biurokracją, urzędami itd. Bez niej byśmy zginęli.

Ostatnia grupa wyzwań dotyczyła aspektów organizacji samego ekosystemu startupowego. Czterech rozmówców wprost stwierdziło, iż brakuje im wiedzy 
w zakresie zarządzania przedsięwzięciem biznesowym. Większość badanych była zgodna, iż kluczowego wsparcia w tym zakresie mogą dostarczyć mentorzy, czyli bardziej doświadczeni przedsiębiorcy, którzy w środowisku startupowym chętnie dzielą się wiedzą. Największą barierą w dostępie do ich wiedzy jest brak koordynacji. Początkujący przedsiębiorcy nie wiedzą, do kogo się zwrócić z danym problemem.

G: Jak zaczynałem, to bardzo sobie ceniłem opinię ludzi mądrzejszych od siebie... [...] Ważny jest dostęp do nich. Teraz, to jak potrzebuję pomocy, to się z kimś umawiam i po prostu z nim rozmawiam.

A: [...] nie wiadomo, do kogo iść z problemem. Raczej staram się szukać po znajomych, niż zwracać do jakiś instytucji. To jest trudność - nie ma instytucjonalnej organizacji tutorów.

C: Na początku, oprócz finansowania brakuje mentorów. Nie ma w Krakowie klastra mentorów. Nie wiadomo do kogo iść. Jest problem z zaufaniem do mentorów, nie wiadomo komu ufać.

Badani byli w większości zgodni, iż środowisko startupowe powinno być lepiej zorganizowane, szczególnie na szczeblu lokalnym. Skrajne opinie budzi jednak zaangażowanie władz publicznych w jego koordynację. Rozmówca oznaczony jako F uważa, iż „Miasto powinno nałożyć nakładkę na istniejącą społeczność startupową", a zdaniem B Urząd Miasta powinien mieć własny fundusz inwestycyjny, wspierający inicjatywy biznesowe powiązane z działalnością miasta (np. system sterowania ruchem czy urządzenia antysmogowe). Z kolei C określił działania Urzędu Miasta jako próbę ,podszycia się pod działania oddolne”, a w opinii respondenta I „ekosystem powinien być budowany wyłącznie przez przedsiębiorców”.

Większość respondentów wśród czynników blokujących rozwój krakowskiego ekosystemu startupowego wymieniła sposób funkcjonowania uczelni wyższych. Sześciu z badanych stwierdziło, iż program studiów nie kształci kompetencji przedsiębiorczych wśród studentów. Czterech respondentów wskazało na niechęć uczelni wyższych do współpracy z biznesem.

C: Na studiach nie było nic o budowaniu własnej firmy, sprzedawaniu pomysłów i ich weryfikacji, sposobie zarządzania firmą [...] Gdyby studia to uwzględniały, to w Krakowie mielibyśmy wysyp startupów.

A: Uczelnie są hermetyczne, trzeba używać kontaktów osobistych, aby nawiązać współpracę. 


\section{Podsumowanie i wnioski}

W pierwszej części artykułu omówiono wybrane pośrednie i bezpośrednie instrumenty proinnowacyjnej polityki gospodarczej oraz specyfikę organizacji typu startup, jako elementu systemu innowacji. W drugiej części przedstawiono wyniki badań własnych opartych na analizie dokumentów i wywiadach pogłębionych, których celem była identyfikacja wyzwań i barier rozwojowych krakowskich startupów.

Podsumowując opisane wyniki i uzupełniając je obserwacjami uczestniczącymi, które autor prowadził od stycznia 2015 do maja 2018 roku (angażując się w działania wspierające krakowski ekosystem startupowy), można wyciągnąć następujące wnioski:

1. Środowisko startupowe ogólnie negatywnie ocenia bezpośrednie instrumenty wsparcia, takie jak granty czy szkolenia organizowane na zlecenie instytucji publicznych. Także dotychczasowy system finansowania uczelni wyższych postrzegany jest jako bariera rozwoju innowacyjnej przedsiębiorczości.

2. Najbardziej preferowaną formą wsparcia kapitałowego na wczesnym etapie rozwoju startupu jest inwestycja funduszu inwestycyjnego, który oprócz środków finansowych wnosi także doświadczenie biznesowe. $\mathrm{Z}$ tego punktu widzenia pozytywnie należy ocenić takie działania, jak realizowany przez NCBiR program Bridge Alfa, który polega na dotowaniu ze środków publicznych funduszy inwestycyjnych $\mathrm{z}$ kapitałem prywatnym.

3. Badani często wymieniali trzy bariery rozwoju startupów: brak wspólnego miejsca spotkań środowiska (wymiar fizyczna), brak strony internetowej integrującej wszystkie informacje na temat ekosystemu (wymiar wirtualny) oraz niedostateczna liczba spotkań branżowych (wymiar kontekstowy). Są to trzy wymiary przestrzeni, bardzo charakterystyczne dla współczesnych ekosystemów innowacji [Pachura 2017].

4. Prowadzona przez władze publiczne polityka gospodarcza powinna uwzględniać fakt, że startupy nie działają w pojedynkę, ale są elementem ekosystemu innowacji, który powinien być wspierany jako całość. Na przestrzeni lat 2015-2018 w Krakowie powstało kilka organizacji działających na rzecz ekosystemu startupowego, jednak nadal brakuje jego koordynacji. Mimo postulatów tego środowiska władze Krakowa nie prowadzą polityki zmierzającej do integracji istniejących wydarzeń czy instytucji, lecz tworzą nowe byty, np. „Krakowski Tydzień Startupów”, czy ogłaszając konkurs grantowy, zwiększając poziom konkurencji w ramach ekosystemu.

Nowoczesne przedsiębiorstwa oparte na innowacjach wymagają wsparcia w postaci nowoczesnej polityki gospodarczej. Władze publiczne podejmują szereg działań w celu wspierania przedsięwzięć startupowych. Rządowe programy, takie jak Bridge Alfa czy ScaleUP, zdają się odpowiadać na realne potrzeby tego środowiska. Z pewnością korzystną zmianą prawną jest nowa konstrukcja ulgi podatkowej na innowacje, z której pośrednio (poprzez generowanie popytu na ich produkty) sko- 
rzystają także startupy. Krokiem w dobrym kierunku są też prace legislacyjne nad prostą spółką akcyjną, której konstrukcja umożliwi startupom łatwiejszy dostęp do kapitału, np. poprzez mechanizm crowdfundingu.

Gorzej z perspektywy oczekiwań środowiska startupowego należy ocenić klasyczne instrumenty wsparcia bezpośredniego, takie jak bony na doradztwo, granty na badania czy organizowanie przez instytucje publiczne spotkań, szkoleń i konferencji. Sporym wyzwaniem, a zarazem sugestią kierunku dalszych badań dla środowiska naukowego jest wypracowanie skutecznych metod ewaluacji tego typu instrumentów. Miasto Kraków oraz województwo małopolskie wydają łącznie ponad 800000 zł rocznie wyłącznie na organizację kilkudziesięciu wydarzeń startupowych, nie dysponując w zasadzie żadnymi narzędziami, którymi mogłyby oceniać efektywność tych projektów.

Zaprezentowane w artykule wyniki badań mają silne ograniczenia związane z przyjętą metodologią. Badania jakościowe ze swej istoty nie pozwalają na zbyt daleko idące uogólnienia. Analizę prowadzono wyłącznie w krakowskim ekosystemie startupowym, jednak zaprezentowane wnioski mogą mieć walor praktyczny dla osób tworzących proinnowacyjne polityki publiczne w szerszym wymiarze.

\section{Literatura}

Adamczyk M., 2016, An attempt to define the concept of start-up company based on inductive research, QUAERE 2016: reviewed proceedings of the interdisciplinary scientific international conference for $\mathrm{PhD}$ students and assistants, s. 67-74, http:/www.vedeckekonference.cz/library/proceedings/ quaere_2016.pdf.

Blank S.G., Dorf B., 2013, Podręcznik startupu. Budowa wielkiej firmy krok po kroku, Helion, Gliwice.

Bursiak, L., 2013, Diagnoza i pozycjonowanie sytuacji finansowej firm start-up oraz spółek z rynku NewConnect w roku 2011, Zeszyty Naukowe Uniwersytetu Szczecińskiego. Finanse. Rynki finansowe. Ubezpieczenia, nr 59, s. 49-58.

Charmaz K., 2009, Teoria ugruntowana. Praktyczny przewodnik po analizie jakościowej, Wydawnictwo Naukowe PWN, Warszawa.

Gemzik-Salwach A., 2014, Wykorzystanie metody Dave'a Berkusa do analizy potencjału rozwojowego firm start-up w Polsce, Acta Universitatis Lodziensis. Folia Oeconomica, nr 2(300).

Jegorow D., 2017, Rozwój przedsiębiorczości indywidualnej przy wsparciu funduszy europejskich, Prace Naukowe Uniwersytetu Ekonomicznego we Wrocławiu, nr 475, Problemy ekonomii, polityki ekonomicznej i finansów publicznych, s. 65-75.

Konecki K., 2012, Studia z metodologii badań jakościowych. Teoria ugruntowana, wyd. 1, 2000, w druku na żądanie, Wydawnictwo Naukowe PWN, Warszawa.

Korpysa J., 2012, Uwarunkowania przedsiębiorczości indywidualnej przedsiębiorstw typu start-up, Studia Ekonomiczne Regionu Łódzkiego, nr 8, s. 377-388.

Kulczycki M., 2014, Bariery i możliwości finansowania przez banki rozwoju małych i średnich przedsiębiorstw, Zeszyty Naukowe Uczelni Vistula, nr 35, s. 151-176.

Orłowski W., 2013, Komercjalizacja badań naukowych w Polsce. Bariery i możliwości ich przełamania, PwC Polska, Warszawa, http://www.ncbr.gov.pl/gfx/ncbir/userfiles/_public/aktualnosci/ komercjalizacja_badan_naukowych_w_polsce_-_prof._w._orlowski.pdf. 
Pachura P., 2017, Identyfikacja relacji organizacyjnych w kontekście ontologii przestrzeni, Organizacja i Kierowanie, nr 2, s. 41-52.

Piątyszek-Pych A., 2017, Polityka wspierania klastrów w Unii Europejskiej, Prace Naukowe Uniwersytetu Ekonomicznego we Wrocławiu, nr 477, Gospodarka lokalna i regionalna w teorii i praktyce, s. 207-219.

Płoszajski P., 2011, Management on the edge of chaos. Challenges of the petabyte age, Journal of Management and Financial Sciences 4, nr 5, s. 54-67.

Puślecki Z.W., 2017, Model potrójnej helisy (Triple Helix) we wzroście efektów innowacyjnych i konkurencyjności, Prace Naukowe Uniwersytetu Ekonomicznego we Wrocławiu, nr 475, Problemy ekonomii, polityki ekonomicznej i finansów publicznych, s. 238-257.

Ries E., 2011, The lean startup: How today's entrepreneurs use continuous innovation to create radically successful businesses, Crown Publishing Group, New York.

Skala A., 2017, Spiralna definicja startupu, Przegląd Organizacji, nr 9, s. 33-39.

Smus T.R., 2014, Finansowanie start-upów w Polsce, Zeszyty Naukowe Uczelni Vistula, nr 35, s. $217-231$.

Urmański J. (red.), 2016, Komercjalizacja badań naukowych. Spojrzenie inwestorów i naukowców, MIT Enterprise Forum Poland, http://www.ncbr.gov.pl/gfx/ncbir/userfiles/_public/aktualnosci/raport_komercjalizacja_badan_2016.pdf.

Węgrzyn G., 2014, Zróżnicowanie innowacji w sektorze ustug w krajach Unii Europejskiej, Prace Naukowe Uniwersytetu Ekonomicznego we Wrocławiu, nr 353, Usługi 2014 Sektor usług - uwarunkowania i tendencje rozwoju, s. 229-239.

Zegarowicz Ł., Wildowicz-Giegiel A., 2017, Wspieranie działalności B $+R$ a efekt wypychania w krajach OECD, Prace Naukowe Uniwersytetu Ekonomicznego we Wrocławiu, nr 475, Problemy ekonomii, polityki ekonomicznej i finansów publicznych, s. 415-428.

Żabiński A., 2015, Realizacja funkcji stymulacyjnej w uldze na zakup nowych technologii, Prace Naukowe Uniwersytetu Ekonomicznego we Wrocławiu, nr 402, Polityka ekonomiczna, s. 409-421. 